\title{
Assessment of the Balanced Development of an Innovation-Oriented Regional Economic System
}

\author{
Victoriya Kolesnikova*, Larisa Chudinova and Andrey Chugunov \\ Voronezh State Technical University, Voronezh, Russia
}

\begin{abstract}
The regulation of the processes of socio-economic development of economic systems is carried out in an extreme situation caused, including, by global hypercompetitiveness. The contradictions are especially acute in the economic systems, developing according to the innovation model. The work substantiates, that in the current conditions, increased attention should be paid to the balance of development of innovation-oriented economic systems. To identify the fact of balance and directions for its maintenance, a methodology for assessing the level of balance of the economic system is proposed. Within the framework of this methodology, it is recommended to assess the balance of development according to three functional components - market, production and personnel with the singling out four levels absolute, relative, conditional balance and imbalance. Three positions are recommended as criteria - resource availability, efficiency and potential, which imply quantitative certainty, reflected in the system of indicators, grouped by functional components of balance. Objective difficulties, arising in the process of assessing the level of balanced development of the economic system can be compensated for by the multivariance in the system of assessed indicators and the criteria for their selection. The technique received practical approval according to the data of the Voronezh region.
\end{abstract}

\section{Introduction}

Socio-economic development of the economic system is a multidimensional and complex process, that should be considered as the achievement of a set of various social and economic goals [1]. The regulation of this process is currently taking place in an extreme situation, as the processes of globalization are intensifying, the results of innovative activity are spreading at a high speed, the social structure is becoming more complex, which causes many socioeconomic problems, including the deterioration of the environment, the decline in the consumer purchasing power, rise in unemployment levels, etc. [2, 3]. These problems are especially acute in the process of development of innovation-oriented economic systems (IOES), capable of purposefully carrying out innovative activity, based on a high level of adaptability, organization, resource saving, efficiency. Their leveling is possible with the help of effective management of the balanced development of the specified economic system.

In the process of studying the prospects for the development of IOES, it is important not only to determine the fact of the balance of this system or its absence, but also to identify the

\footnotetext{
*Corresponding author: artvik1973@yandex.ru
} 
levels of balance, as well as "pain points" and "points of growth". For these purposes, it is advisable to assess the level of balance of the IOES, which can be used to identify areas for maintaining the existing, increasing decreasing or losing balance of the economic system.

\section{Research Methodology}

The basis for the research of the features of the balanced development of IOES was the dialectical, historical and logical general scientific methods, which allowed to describe the issues under study in unity and historical chronological sequence with simultaneous logical consolidation. As a result, it was determined, that under the balanced development of IOES at the regional level, we understand the process of achieving proportionality relations, aimed at a harmony of the interests of society, business and government authorities through the implementation of consensual interaction between the subjects of the regional economy. The balanced development of IOES should be considered in three aspects - temporary, structural and targeted. Therefore, the balanced development of the IOES is manifested as:

- the qualitative state of the economic system, which consists in a harmonious combination of interests of network stakeholders of the innovative development of this system;

- the quantitative state of the economic system, characterized by the proportionality between the traditional and innovative development of the system under consideration;

- the dynamism of the economic system, reflected in the timeliness and rate of variability, with the ability to preserve, within a certain time period, stable values of indicators, characterizing socio - economic development.

Based on the systemic and synergistic approaches, using the methods of scientific abstractions, analysis and synthesis, a methodology for assessing the balance of the development of IOES at the regional level was formed. At the first stage, the balance of the innovative development of the economic system is assessed, based on the research of the region's position in the field of innovative activity and innovative potential. The methodology and results of assessing the balance of innovative development of the economic system on the example of the Voronezh region are resulted in [4,5]. At the second stage, the level of balanced development of the innovation-oriented regional economic system is assessed. We consider it expedient to single out four levels, namely: absolute balance, relative balance, conditional balance and imbalance. The characteristics of the classification levels of the balanced development of the IOES are presented in Table 1.

Table 1. The characteristics of the classification levels of the balanced development of the IOES.

\begin{tabular}{|c|c|c|}
\hline $\begin{array}{c}\text { Classificat } \\
\text { ion level }\end{array}$ & $\begin{array}{c}\text { Brief } \\
\text { characteristic of the } \\
\text { level }\end{array}$ & $\begin{array}{c}\text { Qualitative } \\
\text { characteristic of the balance } \\
\text { of the development of the IOES }\end{array}$ \\
\hline $\begin{array}{l}\text { Absolute } \\
\text { balance } \\
\text { (A) }\end{array}$ & $\begin{array}{l}\text { The economic system } \\
\text { is in a state of } \\
\text { achieving the optimal } \\
\text { proportionality of the } \\
\text { traditional and } \\
\text { innovative socio- } \\
\text { economic } \\
\text { development of the } \\
\text { system with an } \\
\text { absolute harmony of } \\
\text { stakeholders' interests } \\
\text { in the effective use of } \\
\text { factors, that ensure } \\
\text { the sustainable } \\
\text { functioning and }\end{array}$ & $\begin{array}{l}\text { All manufactured innovative products are successfully } \\
\text { sold with a continuous increase in the share of these } \\
\text { products in the gross regional product. The position of } \\
\text { the economic system in the interregional market is stable. } \\
\text { With an increase in the volume of investments in } \\
\text { intellectual property objects, the return on invested } \\
\text { capital is above the average for the district. The share of } \\
\text { organizations, performing research and development in } \\
\text { the total number of organizations is higher, than the } \\
\text { regional average. The technical and economic indicators } \\
\text { of the production of innovative products are higher, than } \\
\text { the regional average values. Advanced production } \\
\text { technologies are actively developed and used. The } \\
\text { quantitative and qualitative staff structure, engaged in }\end{array}$ \\
\hline
\end{tabular}




\begin{tabular}{|c|c|c|}
\hline & $\begin{array}{c}\text { accelerated } \\
\text { development of the } \\
\text { IOES. }\end{array}$ & $\begin{array}{l}\text { research and development, is being improved, the } \\
\text { personnel potential is high. }\end{array}$ \\
\hline $\begin{array}{l}\text { Relative } \\
\text { balance } \\
(\mathrm{R})\end{array}$ & $\begin{array}{l}\text { The economic system } \\
\text { is functioning } \\
\text { successfully, but there } \\
\text { are some difficulties } \\
\text { with development, } \\
\text { which are overcome } \\
\text { by including } \\
\text { adaptation } \\
\text { mechanisms }\end{array}$ & $\begin{array}{l}\text { Manufactured innovative products are sold, their share in } \\
\text { the gross regional product is maintained at a stable level. } \\
\text { The position of the economic system in the interregional } \\
\text { market is stable, but there may be temporary negative } \\
\text { movements for certain positions. The volume of } \\
\text { investments in intellectual property objects is stable, the } \\
\text { return on invested capital is at the average regional level. } \\
\text { The share of organizations, performing research and } \\
\text { development in the total number of organizations } \\
\text { corresponds to the average regional values. The technical } \\
\text { and economic indicators of the production of innovative } \\
\text { products corresponds to the average regional values. } \\
\text { Advanced production technologies are developed and } \\
\text { used. The quantitative and qualitative staff structure, } \\
\text { engaged in research and development, is stable, the } \\
\text { personnel potential is not lower, than the average regional } \\
\text { level. }\end{array}$ \\
\hline $\begin{array}{l}\text { Condition } \\
\text { al balance } \\
\text { (C) }\end{array}$ & $\begin{array}{l}\text { There are chronic } \\
\text { violations of the most } \\
\text { important parameters } \\
\text { in the functioning of } \\
\text { the economic system, } \\
\text { its development is } \\
\text { difficult }\end{array}$ & $\begin{array}{l}\text { Not the entire volume of manufactured innovative } \\
\text { products is successfully sold, and its share in the volume } \\
\text { of the gross regional product tends to decrease. The } \\
\text { position of the economic system in the interregional } \\
\text { market is unstable, there are periodic negative } \\
\text { movements for most positions. The volume of } \\
\text { investments in intellectual property objects is decreasing, } \\
\text { the return on invested capital is below the regional } \\
\text { average. The share of organizations, performing research } \\
\text { and development, in the total number of organizations is } \\
\text { decreasing. The technical and economic indicators of the } \\
\text { production of innovative products are below the regional } \\
\text { average values. The number of advanced manufacturing } \\
\text { technologies being developed and used is decreasing. The } \\
\text { number of personnel, engaged in research and } \\
\text { development, is stable, but the qualitative staff structure } \\
\text { requires renewal, the personnel potential is below the } \\
\text { average regional level. }\end{array}$ \\
\hline $\begin{array}{l}\text { Imbalance } \\
\text { (I) }\end{array}$ & $\begin{array}{l}\text { In the functioning of } \\
\text { the economic system, } \\
\text { chronic violations of } \\
\text { the basic parameters } \\
\text { are observed, the } \\
\text { system does not } \\
\text { develop }\end{array}$ & $\begin{array}{l}\text { Manufactured innovative products are sold partly, their } \\
\text { share in the gross regional product is decreasing. The } \\
\text { position of the economic system in the interregional } \\
\text { market is unstable, negative trends are observed for most } \\
\text { positions. The volume of investments in intellectual } \\
\text { property objects is decreasing, the return on invested } \\
\text { capital is significantly lower, than the regional average. } \\
\text { The share of organizations, performing research and } \\
\text { development, in the total number of organizations is } \\
\text { decreasing. The technical and economic indicators of the } \\
\text { production of innovative products are significantly below } \\
\text { the regional average values. The number of advanced } \\
\text { manufacturing technologies being developed and used is } \\
\text { significantly decreasing. The number of personnel, } \\
\text { engaged in research and development, is decreasing, the } \\
\text { qualitative staff structure requires renewal, the personnel } \\
\text { potential is significantly below the average regional level. }\end{array}$ \\
\hline
\end{tabular}

The conclusion about the presence of one or another qualification level of balance should be based on an in-depth analysis of three positions in the functioning and development 
prospects of the IOES, namely, resource availability, efficiency and potential. These criteria assume quantitative certainty, reflected in the system of indicators, grouped according to the functional components of balance - market, production and personnel balance. Market balance in relation to IOES is understood as the achievement of harmonious proportions between demand and supply for traditional and innovative goods, works, services, in which the existing needs are fully provided with the necessary resources. Production balance is characterized by the release of the maximum volume of innovative products at the lowest possible costs, based on the compliance with optimal ratios between the size of useful production areas and the time of their use, production volumes and the need for specialized equipment, as well as the funds, necessary for its acquisition, using progressive and traditional technologies. Personnel balance is understood as the optimal proportionality in the qualitative and quantitative staff composition and structure of those, employed in the production of traditional and innovative goods, works and services.

The main features of the assessed types of balanced development of IOES are presented in Table 2.

Table 2. Features of the types of balanced development of IOES.

\begin{tabular}{|c|c|}
\hline $\begin{array}{l}\text { Types of balanced } \\
\text { development of } \\
\text { IOES }\end{array}$ & Features of balanced development of IOES \\
\hline $\begin{array}{l}\text { Market balance } \\
\text { (MB) }\end{array}$ & $\begin{array}{l}\text { All manufactured innovative products are sold. The capacity of the market } \\
\text { for manufactured innovative goods, works and services is increasing. The } \\
\text { share of manufactured and sold innovative goods, works and services in the } \\
\text { total volume of goods, works and services is growing. In the volume of the } \\
\text { gross regional product, there is an increase in the volume of innovative } \\
\text { goods, works and services. There is an acceptable dynamics of investments } \\
\text { in intellectual property in relation to the volume of innovative products and } \\
\text { to the number of organizations, performing research and development. } \\
\text { There is a positive trend towards an increase in the number of } \\
\text { organizations, performing research and development, in the total number of } \\
\text { enterprises and organizations. Capital costs for information, computing and } \\
\text { telecommunications equipment are increasing. }\end{array}$ \\
\hline $\begin{array}{l}\text { Production } \\
\text { balance (PB) }\end{array}$ & $\begin{array}{l}\text { There is a positive trend in the volume of innovative goods, works, services } \\
\text { per } 1 \text { ruble of costs, invested in technological innovations, per } 1 \text { ruble of } \\
\text { internal costs for research and development, and per } 1 \text { ruble of investments } \\
\text { in fixed assets. There is an acceptable dynamics of investment in fixed } \\
\text { assets, internal current costs and capital costs for the purchase of } \\
\text { equipment, internal material costs. In the value of fixed assets, the share of } \\
\text { the value of fixed assets in the field of information and communications is } \\
\text { growing. There is a positive trend in the number of developed and used } \\
\text { advanced production technologies in terms of the total number of } \\
\text { enterprises. }\end{array}$ \\
\hline $\begin{array}{l}\text { Personnel balance } \\
\text { (PB) }\end{array}$ & $\begin{array}{l}\text { The number of personnel, engaged in research and development, is } \\
\text { growing. The share of researchers in the number of personnel, engaged in } \\
\text { research and development, is increasing. There is an acceptable dynamics } \\
\text { of internal current costs for remuneration of personnel, engaged in research } \\
\text { and development, as well as investments in intellectual property objects. } \\
\text { The labor productivity of personnel, engaged in research and development, } \\
\text { is growing. The growth rate of labor productivity of personnel, engaged in } \\
\text { research and development, exceeds the growth rate of the real wage of the } \\
\text { specified personnel. There is a positive trend in the number of filed and } \\
\text { issued patent applications per } 1,000 \text { people, engaged in research and } \\
\text { development. }\end{array}$ \\
\hline
\end{tabular}

The combination of signs of market, production and personnel balance allow to form an manner of the balanced development of an innovation-oriented economic system, which is 
resulted in the successful adaptation of the regional economic system to innovations of various types. The theory, methodology and practice of indicative management of industrial enterprises in the innovation sphere, developed by N.V. Sirotkina, were the basis for the development of a set of indicators for assessing the balanced development of the IOES [6,7]. The list of indicators is shown in Table 3.

Table 3. Indicators for assessing the balanced development of the IOES.

\begin{tabular}{|c|c|c|}
\hline $\begin{array}{l}\text { Type of } \\
\text { balance }\end{array}$ & $\begin{array}{c}\text { Criteria } \\
\text { for } \\
\text { assessmen } \\
\mathrm{t}\end{array}$ & $\begin{array}{l}\text { Balance assessment indicators } \\
\text { of the development of the IOES }\end{array}$ \\
\hline \multirow[t]{9}{*}{$\begin{array}{l}1 \text { Market } \\
\text { balance }\end{array}$} & \multirow{3}{*}{$\begin{array}{l}1.1 \\
\text { Resource } \\
\text { availabilit } \\
\mathrm{y}\end{array}$} & $\begin{array}{l}\text { 1.1.1 The ratio of investments in intellectual property objects to the } \\
\left.\text { number of organizations, performed research and development ( } \mathrm{I}_{1.1 .1}\right)\end{array}$ \\
\hline & & $\begin{array}{l}\text { 1.1.2 The ratio of investments in intellectual property objects to } \\
\text { investments in fixed assets }\left(\mathrm{I}_{1.1 .2}\right)\end{array}$ \\
\hline & & $\begin{array}{l}\text { 1.1.3 The ratio of investments in intellectual property objects to the } \\
\text { volume of innovative goods, works, services }\left(\mathrm{I}_{1.1 .3)}\right.\end{array}$ \\
\hline & \multirow[t]{3}{*}{$\begin{array}{l}1.2 \\
\text { Efficiency }\end{array}$} & $\begin{array}{l}\text { 1.2.1 The share of the volume of innovative goods, works, services in } \\
\text { the total volume of shipped goods, works, services }\left(\mathrm{I}_{1.2 .1}\right)\end{array}$ \\
\hline & & 1.2.2 The level of innovative activity of organizations $\left(\mathrm{I}_{1.2 .2}\right)$ \\
\hline & & $\begin{array}{l}\text { 1.2.3 The ratio of the volume of innovative goods, works, services to the } \\
\text { volume of the gross regional product }\left(\mathrm{I}_{1.2 .3}\right)\end{array}$ \\
\hline & \multirow[t]{3}{*}{$\begin{array}{l}1.3 \\
\text { Potential }\end{array}$} & $\begin{array}{l}\text { 1.3.1 The ratio of the volume of innovative goods, works, services to the } \\
\text { number of organizations, performed research and development }\left(\mathrm{I}_{1.3 .1}\right)\end{array}$ \\
\hline & & $\begin{array}{l}\text { 1.3.2 The share of organizations, performed research and development, } \\
\text { in the total number of enterprises and organizations }\left(\mathrm{I}_{1.3 .2}\right)\end{array}$ \\
\hline & & $\begin{array}{l}\text { 1.3.3 The ratio of investment in education to the volume of innovative } \\
\text { goods, works, services }\left(\mathrm{I}_{1.3 .3)}\right.\end{array}$ \\
\hline \multirow{9}{*}{$\begin{array}{l}2 \\
\text { Productio } \\
\text { n balance }\end{array}$} & \multirow{3}{*}{$\begin{array}{l}2.1 \\
\text { Resource } \\
\text { availabilit } \\
\text { y }\end{array}$} & $\begin{array}{l}\text { 2.1.1 The ratio of current internal costs for purchasing equipment to the } \\
\text { number of organizations, performed research and development }\left(\mathrm{I}_{2.1 .1}\right)\end{array}$ \\
\hline & & $\begin{array}{l}\text { 2.1.2 The ratio of internal material costs to the number of organizations, } \\
\text { performed research and development }\left(\mathrm{I}_{2.1 .2}\right)\end{array}$ \\
\hline & & $\begin{array}{l}2.1 .3 \text { The ratio of capital costs for equipment to the number of } \\
\text { organizations, performed research and development }\left(\mathrm{I}_{2.1 .3}\right)\end{array}$ \\
\hline & \multirow[t]{3}{*}{$\begin{array}{l}2.2 \\
\text { Efficiency }\end{array}$} & $\begin{array}{l}\text { 2.2.1 The ratio of the volume of innovative goods, works, services to the } \\
\text { volume of costs for innovative activity of organizations (technological } \\
\left.\text { innovations) ( } \mathrm{I}_{2.2 .1}\right)\end{array}$ \\
\hline & & $\begin{array}{l}\text { 2.2.2 The ratio of the volume of innovative goods, works, services to } \\
\text { investments in fixed assets }\left(\mathrm{I}_{2.2 .2}\right)\end{array}$ \\
\hline & & $\begin{array}{l}2.2 .3 \text { The ratio of the number of used advanced production technologies } \\
\text { to the total number of enterprises }\left(\mathrm{I}_{2.2 .3}\right)\end{array}$ \\
\hline & \multirow[t]{3}{*}{$\begin{array}{l}2.3 \\
\text { Potential }\end{array}$} & $\begin{array}{l}\text { 2.3.1 The ratio of the volume of innovative goods, works, services to the } \\
\text { volume of internal costs on research and development }\left(\mathrm{I}_{2.3 .1}\right)\end{array}$ \\
\hline & & $\begin{array}{l}\text { 2.3.2 The ratio of investments in fixed assets to the number of } \\
\text { organizations, performed research and development }\left(\mathrm{I}_{2.3 .2}\right)\end{array}$ \\
\hline & & $\begin{array}{l}\text { 2.3.3 The ratio of the number of developed advanced production } \\
\text { technologies to the number of organizations, performed research and } \\
\text { development }\left(\mathrm{I}_{2.3 .3}\right)\end{array}$ \\
\hline \multirow[t]{2}{*}{$\begin{array}{l}3 \\
\text { Personnel } \\
\text { balance }\end{array}$} & \multirow{2}{*}{$\begin{array}{l}3.1 \\
\text { Resource } \\
\text { availabilit } \\
\text { y }\end{array}$} & $\begin{array}{l}\text { 3.1.1 The ratio of the number of personnel, engaged in research and } \\
\text { development, to the average annual number of people, engaged in the } \\
\left.\text { regional economy (per } 1,000 \text { people) ( } I_{3.1 .1}\right)\end{array}$ \\
\hline & & $\begin{array}{l}\text { 3.1.2 The ratio of the number of personnel, engaged in research and } \\
\text { development, to the number of organizations, performed research and } \\
\text { development }\left(I_{3.1 .2)}\right.\end{array}$ \\
\hline
\end{tabular}




\begin{tabular}{|c|c|}
\hline & $\begin{array}{l}\text { 3.1.3 The ratio of investments in intellectual property objects to the } \\
\text { number of personnel, engaged in research and development }\left(\mathrm{I}_{3.1 .3}\right)\end{array}$ \\
\hline \multirow[t]{3}{*}{$\begin{array}{l}3.2 \\
\text { Efficiency }\end{array}$} & $\begin{array}{l}\text { 3.2.1 The real wage of personnel, engaged in research and development } \\
\text { (the ratio of internal current costs for remuneration to the number of } \\
\left.\text { personnel, engaged in research and development) ( } I_{3.2 .1}\right)\end{array}$ \\
\hline & $\begin{array}{l}\text { 3.2.2 Labor productivity of personnel, engaged in research and } \\
\text { development (the ratio of the volume of innovative goods, works, } \\
\text { services to the number of personnel, engaged in research and } \\
\left.\text { development) ( } \mathrm{I}_{3.2 .2}\right)\end{array}$ \\
\hline & $\begin{array}{l}\text { 3.2.3 The ratio of the number of issued patent applications per } 1000 \\
\text { people, engaged in research and development }\left(I_{3.2 .3)}\right.\end{array}$ \\
\hline \multirow[t]{3}{*}{$\begin{array}{l}3.3 \\
\text { Potential }\end{array}$} & $\begin{array}{l}\text { 3.3.1 The share of researchers in the total number of personnel, engaged } \\
\text { in research and development }\left(I_{3.3 .1}\right)\end{array}$ \\
\hline & $\begin{array}{l}\text { 3.3.2 The ratio of the number of researchers to the number of } \\
\text { organizations, performed research and development (I I.3.2) }\end{array}$ \\
\hline & $\begin{array}{l}\text { 3.3.3 The ratio of the number of filed patent applications per } 1,000 \\
\text { people, engaged in research and development }\left(I_{3.3 .3}\right)\end{array}$ \\
\hline
\end{tabular}

By comparing the quantitative characteristics of the indicators with the average values for the district by expert means, it is possible to define the level of balanced development of the IOES for each indicator. Further, a direct assessment of the market, production and personnel balance is carried out.

The basic foundation for assessing market, production and personnel balance was the methodology for assessing the economic soundness of an enterprise by Merzlikina G.S. and Shakhovskoy L.S. [8]. According to the proposed methodology, one point is assigned to each individual indicator. All estimates obtained are summed up according to the corresponding level of balance. The definitive estimate is aggregate on the maximum score of the corresponding balance level. In a similar way, the criterion assessment of the balanced development of the IOES is carried out. The results obtained are entered into the normative balance matrix, which can be constructed in percentage terms, taking as the "base" the maximum value for the group of indicators, characterizing the functional components of balance, and recalculating the rest of the indicators relative to the "base". The proposed scale of compliance for a quantitative assessment of the qualitative levels of balanced development of the IOES is presented in Table 4.

Table 4. The scale of compliance for a quantitative assessment of the qualitative levels of balanced development of the IOES.

\begin{tabular}{|c|c|}
\hline $\begin{array}{c}\text { Qualitative level of } \\
\text { balance }\end{array}$ & $\begin{array}{c}\text { Quantitative assessment of the level of } \\
\text { balance }\end{array}$ \\
\hline Absolute balance & $75-100$ \\
\hline Relative balance & $50-74$ \\
\hline Conditional balance & $35-49$ \\
\hline Imbalance & $0-34$ \\
\hline
\end{tabular}

At the final stage of assessing the balanced development of an innovation-oriented regional economic system, a final conclusion is being prepared, and a system of measures is being developed to improve the obtained level of balance and eliminate negative trends.

\section{Findings}

The results of assessing the degree of balance of the innovative development of the Voronezh region are resulted in Table 5 and Figure 1.

Table 5. The assessment of the degree of balance of the innovative development of the Voronezh region. 


\begin{tabular}{|c|c|c|c|c|c|c|}
\hline \multirow{2}{*}{ Period } & \multicolumn{6}{|c|}{ The value of the level } \\
\cline { 2 - 7 } & \multicolumn{2}{|c|}{$\begin{array}{c}\text { relative to the regions - } \\
\text { innovative leaders }\end{array}$} & \multicolumn{3}{c|}{ relative to the average } \\
& $\begin{array}{c}\text { innovation } \\
\text { potential } \\
\text { of the } \\
\text { region }\end{array}$ & $\begin{array}{c}\text { innovative } \\
\text { activity of } \\
\text { the region }\end{array}$ & $\begin{array}{c}\text { balance of } \\
\text { the } \\
\text { innovative } \\
\text { developmen } \\
\text { t of the } \\
\text { region }\end{array}$ & $\begin{array}{c}\text { innovation } \\
\text { potential } \\
\text { of the } \\
\text { region }\end{array}$ & $\begin{array}{c}\text { innovative } \\
\text { activity of } \\
\text { the region }\end{array}$ & $\begin{array}{c}\text { balance of the } \\
\text { innovative } \\
\text { development of } \\
\text { the region }\end{array}$ \\
\hline 2010 & 0.187 & 0.142 & 1.320 & 0.964 & 0.793 & 0.822 \\
\hline 2011 & 0.320 & 0.213 & 1.505 & 0.984 & 0.905 & 0.919 \\
\hline 2012 & 0.250 & 0.196 & 1.276 & 0.943 & 0.924 & 0.980 \\
\hline 2013 & 0.199 & 0.201 & 0.989 & 0.847 & 0.746 & 0.8814 \\
\hline 2014 & 0.269 & 0.196 & 1.373 & 0.777 & 0.758 & 0.976 \\
\hline 2015 & 0.365 & 0.265 & 1.377 & 0.928 & 0.886 & 0.955 \\
\hline 2016 & 0.291 & 0.276 & 1.056 & 0.994 & 0.884 & 0.889 \\
\hline 2017 & 0.240 & 0.219 & 1.097 & 0.856 & 0.883 & 1.032 \\
\hline 2018 & 0.186 & 0.198 & 0.939 & 0.971 & 0.889 & 0.916 \\
\hline 2019 & 0.194 & 0.216 & 0.900 & 0.990 & 0.915 & 0.924 \\
\hline
\end{tabular}

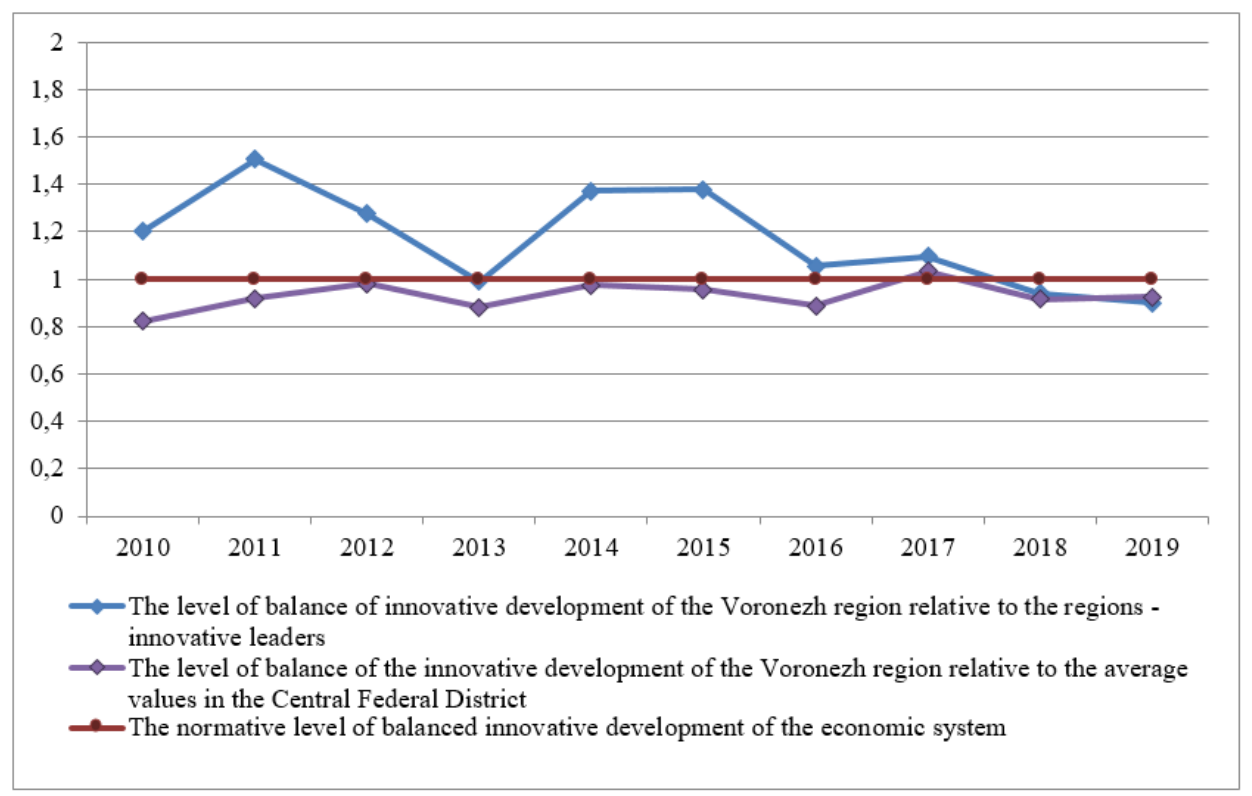

Fig. 1. Dynamics of the level of balance of the innovative development of the Voronezh region.

Thus, the Voronezh region is characterized by significant innovation potential, since it has a high concentration of scientific and research and educational institutions, that provide fundamental research and applied developments in the areas of innovative technologies and modern technical systems. However, when comparing the Voronezh region with the regions - innovative leaders, a certain gap is seen between the available innovative potential and its actual use. By the end of the period under consideration, the innovative development of the Voronezh region can be recognized as sufficiently balanced, and the use of innovative potential is highly effective.

The results of comparing the quantitative characteristics of the indicators of the balance of the Voronezh region with the average values for the Central Federal District in 2019 by functional components are shown in Table 6. 
Table 6. The results of comparing the quantitative characteristics of the indicators of the balance of the Voronezh region in 2019.

\begin{tabular}{|c|c|c|c|c|}
\hline Indicators & $\mathrm{A}$ & $\mathrm{R}$ & $\mathrm{C}$ & I \\
\hline \multicolumn{5}{|c|}{ Market balance } \\
\hline$I_{1.1 .1}$ & & & & $*$ \\
\hline $\mathrm{I}_{1.1 .2}$ & & & & $*$ \\
\hline $\mathrm{I}_{1.1 .3}$ & & & & * \\
\hline $\mathrm{I}_{1.2 .1}$ & $*$ & & & \\
\hline $\mathrm{I}_{1.2 .2}$ & $*$ & & & \\
\hline $\mathrm{I}_{1.2 .3}$ & $*$ & & & \\
\hline $\mathrm{I}_{1.3 .1}$ & & $*$ & & \\
\hline $\mathrm{I}_{1.3 .2}$ & $*$ & & & \\
\hline $\mathrm{I}_{1.3 .3}$ & $*$ & & & \\
\hline Total & 5 & 1 & - & 3 \\
\hline \multicolumn{5}{|c|}{ Production balance } \\
\hline $\mathrm{I}_{2.1 .1}$ & & & & $*$ \\
\hline $\mathrm{I}_{2.1 .2}$ & & & $*$ & \\
\hline $\mathrm{I}_{2.1 .3}$ & & & & $*$ \\
\hline$I_{2.2 .1}$ & $*$ & & & \\
\hline$I_{2.2 .2}$ & & $*$ & & \\
\hline $\mathrm{I}_{2.2 .3}$ & $*$ & & & \\
\hline $\mathrm{I}_{2.3 .1}$ & $*$ & & & \\
\hline$I_{2.3 .2}$ & $*$ & & & \\
\hline $\begin{array}{ll}2.3 .2 .3 \\
\end{array}$ & & $*$ & & \\
\hline Total & 4 & 2 & 1 & 2 \\
\hline \multicolumn{5}{|c|}{ Personnel balance } \\
\hline $\mathrm{I}_{3.1 .1}$ & & & $*$ & \\
\hline $\mathrm{I}_{3.1 .2}$ & & & $*$ & \\
\hline $\mathrm{I}_{3.1 .3}$ & & & & $*$ \\
\hline$I_{3.2 .1}$ & & & $*$ & \\
\hline$I_{3.2 .2}$ & $*$ & & & \\
\hline $\mathrm{I}_{3.2 .3}$ & $*$ & & & \\
\hline$I_{3.3 .1}$ & $*$ & & & \\
\hline$I_{3.3 .2}$ & & & $*$ & \\
\hline$I_{3.3 .3}$ & $*$ & & & \\
\hline Total & 4 & - & 4 & 1 \\
\hline
\end{tabular}

The normative balance matrix of the Voronezh region in 2019 is shown in Table 7.

Table 7. The normative balance matrix of the Voronezh region in 2019.

\begin{tabular}{|c|c|c|c|c|}
\hline \multirow{2}{*}{ Type of the balance } & \multicolumn{3}{|c|}{ Balance criteria } & Total \\
\cline { 2 - 5 } & $\begin{array}{c}\text { Resource } \\
\text { availability }\end{array}$ & Efficiency & Potential & 66.7 \\
\hline Market balance & 0 & 33.35 & 33.35 & 66.7 \\
\hline Production balance & 0 & 33.35 & 33.35 & \\
\hline
\end{tabular}




\begin{tabular}{|c|c|c|c|c|}
\hline Personnel balance & 0 & 22.2 & 22.2 & 44.4 \\
\hline Total & - & 88.9 & 88.9 & 59.27 \\
\hline
\end{tabular}

An assessment of the level of balance of the development of the economic system in the period under study showed, that the Voronezh region has a relative balance with a favorable development trend. The worst situation is observed with the provision of the innovation sphere of the Voronezh region with resources. Nevertheless, the existing significant innovation potential allows to achieve high efficiency in the process of harmonizing the traditional and innovative development of IOES with consensual interaction of the subjects of the regional economy.

\section{Discussion}

The main goals of assessing the balanced development of the IOES of the regional level are: - a comprehensive assessment of the balance of the innovative development of the regional economic system by set of findings - indicators (calculation of specific and generalized findings);

- conducting an interregional integral rating analysis to assess the differences in the levels of balance of the innovative development of the constituent entities of the Russian Federation;

- establishing the influence of the level of the balance of the innovative development on the performance indicators of economic activity in the region;

- identification of reserves for increasing innovation activity and determination of priority areas for the use of identified reserves in the future.

An appropriate assessment of the balance faces objective difficulties, including [9]:

- difficulties with the development of universal indicators, reflecting the balance, since the complexity and dynamism of the processes under consideration determines the constant variability of both the quantitative and qualitative composition of indicators;

- lack of generally accepted norms and standards, recommended values for indicators, characterizing the level of innovative development of the system under consideration;

- formalization of the assessment of the balance of the innovation - oriented economic system, leading to simplification and a certain subjectivity in the assessment procedures.

Most of these difficulties in the assessment can be compensated to a certain extent by developing multivariance in the system of assessed indicators and the criteria for their selection.

It should be noted, that when developing indicators, it almost always necessary to additionally simplify and schematize real phenomena, and therefore, their totality reflects objective reality only with a certain degree of approximation. All this makes it important to constantly work on improving the methodology for assessing the balance of development of innovation - oriented economic systems in accordance with the development of reflected objective reality and as a result of deepening knowledge of real economic systems.

\section{Conclusion}

The use of the proposed methodological development allows to obtain quantitative estimates of the level of balanced development of an innovation - oriented economic system for the entire set of parameters under consideration and use them for flexible response to minor changes in any of them. The calculation of the level of balance of the economic system is based on general indicators, collected centrally and published in the open media [10], which allows to reduce the likelihood of data manipulation and distortion of results in interregional comparisons.

The proposed methodology can be used to assess the balance of development not only of individual regions, but also of enterprises, industries, countries. It allows to comprehensively 
assess the balance of development of IOES at different levels, using a variable set of specific indicators, as well as to carry out a comparative analysis, to identify trends in innovative development and cause-and-effect relations, that led to such development, to determine the main ways to improve the balance of a system, developing according to an innovative model.

\section{References}

1. E.V. Endovitskaya, I.E Risin, Y.I. Treshchevsky, Strategic goals of socio-economic development of regions in the conditions of economic and financial limitations. In the collection: The Future of the Global Financial System: Down-fall or Harmony. Series "Lecture Notes in Networks and Systems" Cham, Switzerland, 229 (2019)

2. O.N. Belenov, S.S. Kiselev, N.V. Sirotkina, M.V. Titova, Lecture Notes in Networks and Systems 87, 482 (2020)

3. E.V. Sumina, I.A. Misineva, T.I. Berg, S.A. Hadzhigurov, Strategy innovative technological development and special-ization region resource economics. In: European Proceedings of Social and Behavioral Sciences EpSBS. Krasnoyarsk Science and Technology City Hall. Krasnoyarsk, 236 (2020)

4. V.B. Artemenko, Competitiveness in the global world: economics, science, technology 9, 15 (2016)

5. V. B. Kolesnikova, L. N. Chudinova, Evaluating the Level of Innovation Activity of the Regional Economic System. Advances in Economics, Business and Management Research, volume 85.2nd International Conference on Economy, Management and Entrepreneurship (ICOEME 2019), Voronezh, 291 (Atlantis Press, 2019)

6. N.V. Sirotkina, Bulletin of the Voronezh State University. Series: Economics and Management 4, 96 (2017).

7. N.V. Sirotkina, Indicative management of industrial enterprises in the innovation sphere: theory, methodology, practice: monograph. Voronezh: Scientific book, 322 p. (2008)

8. G.S. Merzlikina, L.S. Shakhovskaya, Assessment of the economic viability of the enterprise: Monograph, Volgograd, 265 p. (VolgGTU, 1998)

9. Y.I. Treshchevsky, M.B. Tabachnikova, G.N. Franovskaya, V.P. Voronin, Economic and statistical analysis in evaluating the perspectives of structural changes of regions' economy. Advances in Intelligent Systems and Computing 622, 521 (2018)

10. Regions of Russia. Socio-economic indicators. http://www.gks.ru/wps/wcm/connect/rosstat_main/rosstat/ru/statistics/publications/cata log/doc_1138623506156. 